\title{
THE EDUCATIONAL BIOGRAPHIES OF ENGINEERS STARTING ACADEMIC CAREERS: COMPARATIVE PERSPECTIVE OF POLAND AND UKRAINE
}

\author{
Emilia Mazurek \\ Wroclaw University of Science and Technology, Wroclaw, Poland \\ emilia.mazurek@pwr.edu.pl \\ Olena Vynoslavska \\ National Technical University of Ukraine "Igor Sikorsky Kyiv Polytechnic Institute", \\ Kyiv, Ukraine \\ olenavynoslavska@gmail.com
}

\begin{abstract}
The recent changes taking place in the European higher education systems leads to less stable, less secure and less attractive working conditions for academic teachers. Nonetheless, it is observed that the academic profession is attractive for young talented people. The research was aimed at studying educational biographies of engineers who took up $\mathrm{PhD}$ studies at technical universities in order to find out the importance of young people's experience and life history in making important life decisions (i.e. starting academic career). The biographical research was performed based on the material of lifelines and autobiographic essays prepared by $\mathrm{PhD}$ students of technical universities in Poland and Ukraine. The study included 56 participants of 23 to 30 years of age. A typology of biographical narratives was developed as a result of analysis of the research material. Additionally, the crucial similarities and differences between educational biographies of PhD students from Poland and from Ukraine were indicated. On the basis of the research it can be determined that traditional motives of undertaking the academic profession - i.e. curiosity, professional status, and financial rewards - still play a big role. New motives are also appearing: investing oneself and social mission. An academic profession is seen as a possibility of development and autonomy to a greater extent than in the economic sector. However, the lack of guarantee of employment at the university after $\mathrm{PhD}$ studies and lower remuneration in academic structures compared to the economic sector make it difficult to plan one's own future and choose academic career instead of a different career path.
\end{abstract}

Keywords: academic profession; educational biography; higher education; PhD studies; technical university.

\section{Introduction}

The significant transformations in higher education systems in European countries visible during the last half-century have changed the academic profession (Fumasoli, Goastellec \& Kehm, 2015). Massification of academic education that involves consequences in terms of the quality of education, change in the relations between students and academic staff, depreciation of diplomas, as well as restrictions on research funding, escalation of competition between scientific centres and researchers for external funding of research, the necessity of establishing cooperation between universities and employers are just a few examples of changes taking place in the European higher education systems. These transformations utterly crumble the academic status quo, while altering the condition of the academic staff and its prospects for the future. Kwiek (2016) analyses the state of higher education by writing that "Traditional social contact of the state with the academy, making things simpler, meant a large range of academic autonomy, a great freedom of having own time, high professional stability and - with growing difficulty, but still possible to maintain - material status of the middle class. The new contract means withdrawing of the state from all the dimensions of academic work guaranteed so far (...): deteriorating academic autonomy (in the sense of increasing emphasis on the applicable, and not the fundamental nature of research, and thus on the nature of the relationship of the research subject - its public funding), reduced professional stability, decreasing control of having own time and the declining material status" (p. 237). The author accentuated that under current conditions, academic work gradually bears a resemblance to working in a corporation, and simultaneously does not guarantee remuneration at the level offered by corporations (Kwiek, 2016). Therefore, on the whole, it can be concluded that the direction of recent changes taking place in the European higher education systems leads to less stable, less secure and less attractive working conditions for academic teachers. Furthermore, obtaining a $\mathrm{PhD}$ degree does not guarantee employment in academic structures owing to the lack of match between the number of doctoral students and (free) full-time positions at universities.

Therefore, one could assume that the work at the university will be less and less attractive to young people. Meanwhile, there is an upsurge in the number of people undertaking $\mathrm{PhD}$ studies in Poland, the completion of which in most European systems (including Polish and Ukrainian) is the first milestone in the academic career. According to the data of the Central Statistical Office in Poland, the number of PhD students in the 2006/2007 academic year amounted to 31,831 people, while in the 2016/2017 year it

Mazurek, E. \& Vynoslavska, O. (2019). The educational biographies of engineers starting academic careers: comparative perspective of Poland and Ukraine. Advanced Education, 13, 4-10. DOI: 10.20535/2410-8286.153456 
increased to 43,181 people (Baran, 2007). Within 10 years, a substantial increase in the number of doctoral students was observed, but at the same time, a decline in the number of doctoral dissertations commenced has been recorded from 8,267 in the academic year 2006/2007 to 5,209 in 2016/2017 (Zyra, 2017). This means that the trend of undertaking $\mathrm{PhD}$ studies by an increasing number of graduates and abandoning them during their course has revealed itself. At the same time, it is forecasted that the situation in Poland in this area will change after the formation of doctoral schools consistent with the Act of July 20, 2018, on the Law on Higher Education and Science.

As to Ukraine, according to the data of the State Committee of Statistics of Ukraine $(2008,2018)$, at the end of 2006 the number of post-graduate students equalled to 31,293 people, while at the end of 2016 it amounted to 25,963 people, i.e. there was a decrease in the number of post-graduate students by $17 \%$. Within 10 years the number of post-graduate students increased up to 34,653 people (2010), but, in connection with deterioration of the economic situation in the country after the beginning of military actions in the East of Ukraine, since 2015 the number of post-graduate students began to decrease. At the same time, the number of post-graduate students who have defended the dissertations has increased to 1,438 at the end of 2006 up to 1,708 at the end of 2016. Despite low ratio of the number of people who ended postgraduate study and who defended the dissertation (21\% in 2006 and 25.5\% in 2016), in Ukraine, as well as in Poland it indicated the tendency for post-graduate students to refuse to carry out the researches during their course of study. It is possible to assume, that the situation in Ukraine in this area will change with adoption of Resolution of the Cabinet of Ministers of Ukraine dated March 23, 2016 No. 261 "On Approval of the Procedure for Preparing Higher Educational Institutions (Scientific Institutions) for PhD and Doctor of Science Degrees" (2016). The beginning of preparing of post-graduate students for the $\mathrm{PhD}$ degree in Ukraine in 2016/2017 academic year proclaimed by this Resolution is directed on the adaptation of world experience in Ukrainian $\mathrm{PhD}$ programmes. That will make the preparing of post-graduate students for the $\mathrm{PhD}$ degree at technical universities of Poland and Ukraine more similar.

The changes indicated in the higher education systems in Europe and the recalled statistical data were a pretext to form a question regarding the motives behind making a decision on undertaking $\mathrm{PhD}$ studies and starting an academic career by graduates of the leading technical universities in Poland and Ukraine. It is possible to wonder to what extent the traditional motives of conducting scientific research, i.e. curiosity, professional status, and financial rewards called as "puzzle, ribbon, and gold" (Stephan \& Levin, 1992, p. 8), are valid in the face of changes taking place. It was supposed that the biographies of engineers realising $\mathrm{PhD}$ studies constitute a noteworthy context for searching for answers to the question posed.

"A conventional conception of biography sees a life story primarily as a record, usually written, of events in an individual's life, though explanation and interpretation are frequently included" (Dickinson, 1998, p. 71). Theoretical considerations in the field of humanities and social sciences over the concept of biography lead to an alteration in the conventional concept of biography which should be viewed not only as a record of past experiences and events, but also an active process of giving them meanings from the viewpoint of the present. The process of creating a biography is never finite; it is subject to continual reconstruction and renegotiation. It is "an active process that remakes and reshapes past events in order to bring them into line with perceptions of the present" (Dickinson, 1998, p. 71). According to Alheit (2009), biography is the dissonance between the life course and the story about life history. "Life constructions extend beyond what we narrate about our lives. (...) in the course of our lives, we produce more meaning relating to ourselves and our social framework that we can actually have from the perspective of our reflexive biographical concern with self (p.124).

In adult education theory and practice, a biography is perceived as a learning space. In the work of Dominice (2000), an educational biography is seen as an adult education approach. "In this approach, adult learners prepare and share life histories that become vehicles through which these learners can reflect on their educational experiences. Through oral and written narratives, educational biography offers the values of reminiscence and the interpretation of experience and influences upon that experience. (...) its main purpose is to help adults deepen their understanding of their own ways of learning and of their existing knowledge" (p. xv). Educational experiences are connected with formal education, as well as non-formal and informal education (see also Mazurek, 2015). Narrating life histories presents an occasion of recall past events as well as gives them the meanings and connect with self-development.

The main objective of the research was to analyse educational biographies of engineers who took up $\mathrm{PhD}$ studies at technical universities in order to find out the importance of young people's experience and life history in making important life decisions (i.e. starting an academic career). The aim was also to encourage $\mathrm{PhD}$ students to reflect upon the history of their life in the context of an already made decision to start a $\mathrm{PhD}$ programme. 


\section{Methods}

Biographical research was based on the assumptions of the interpretative paradigm, according to which man as homo narrans lives in the world of the story and creates it himself. These stories are the result of negotiations between man and the world which he lives in. In turn, the researcher's task is to "(...) reconstruct what the respondents say, but also to give meaning to what they say by finding a conceptual pattern that lies behind the validation of own learning in the studied bibliographies." (Jurgiel-Aleksander, 2015 , p. 81). The biographical research was performed based on the material of lifelines and autobiographic essays prepared by PhD students at the Wroclaw University of Science and Technology (Poland) and the National Technical University of Ukraine "Igor Sikorsky Kyiv Polytechnic Institute" in Kyiv (Ukraine). According to Gramling and Carr (2004), "Lifelines are a visual depiction of a life history, displaying events in chronological order and noting the importance, or meaning, of events" (p. 207). They "can serve as a retrospective and holistic representations of experiences, helping participants link past experiences with subsequent actions" (Arnault \& Shimabukuro, 2011, p. 315). The participants were instructed to draw their lifelines and mark them with all elements (events, persons, places, etc.) which they considered important in their biographies for the decision to take up $\mathrm{PhD}$ studies and the role of academic teachers. The formal analysis of the participants' lifelines (i.e. temporal and visual level of lifelines) was presented in the text Lifelines in studies on biographic determinants of decisions to take up $\mathrm{PhD}$ studies at a technical university (Mazurek \& Vynoslavska, 2018). Lifelines were supposed to serve as an introduction to the task of writing an autobiographic essay in which participants could elaborate on elements marked on their lifelines. The lifelines and essays were prepared in participants' mother tongues (i.e. in Polish and Ukrainian).

The group of participants was selected according to the principle of purposive sampling. The study included 56 participants (Poland: 28 persons, including 10 women; Ukraine: 28 persons, including 2 women) of 23 to 30 years of age. The average age of a participant was 25 . The majority of participants came from a big city (29 persons), 14 participants were from a medium-size town, 9 from a small town, and 7 from the countryside. The participants were studying the following disciplines: architecture, electronics, IT, management, automatics and robotics, mechanical engineering, and biotechnology.

The analysis and interpretation of the research material (i.e. lifelines and autobiographic narratives) were conducted in accordance with a method of a multi-level analysis and hermeneutic interpretation (Kruchowska, 2010). The first stage of analysis consisted of coding, selecting theme motifs and key categories related to the studied problem in every lifeline and narrative. The second stage consisted of looking for categories that were common to $\mathrm{PhD}$ students of the Wroclaw University of Science and Technology and of the National Technical University of Ukraine "Igor Sikorsky Kyiv Polytechnic Institute" in Kyiv, and for categories that differed in these two groups. Data were organised under each category and reviewed, noting the commonalities and differences. Then, the so-called external interpretation was performed, within which the discovered meanings were compared to theoretical models and empirical studies. Thus, the study was of an explorative character, with an inductive approach to qualitative analysis, assuming no initial categorisations around which the analysis of data is conducted (Gramling \& Carr, 2004; Riessman, 2005).

\section{Results}

By means of the analysis of the lifeline and the autobiographical essays of the PhD students, key categories have been recognised in educational biographies, which were most meaningful to respondents in the context of their learning, development, and finally the decision to start PhD studies. Then, a typology of the respondents' stories was developed.

The first discovered type of story is exemplified by the sentences: Parents claimed that wisdom and knowledge are more significant values than beauty and money. I In my family there are a lot of teachers. This type of story is dominated by a thread of social origin and the role of education in human life. A vital component here is also the reference of some respondents to the teaching and/or academic traditions in the family. Social origin is viewed as a biographical resource. Mentioning noteworthy persons, family members, and frequently emphasising the role they have played in their lives is characteristic of this narrative. There are threads regarding the shaping of interests, forming aspirations and motivating to learn, exposing vital values in life and ways of explaining various phenomena and processes found in the social and cultural world, in nature, technologies, etc. The key factor in shaping the (educational) biography in this type of narrative is the natural realisation of the values conveyed in the environment of primary socialisation and the wish to meet the expectations of noteworthy people. Among the respondents, there were no people whose social origin would be perceived as an impediment to their own education and growth.

The second emphasised type of narrative is reflected in the statement: Favourite game? Playing school! 
Accentuating the passion for teaching others is distinctive for this type of story which has already appeared in childhood and was carried out by playing school with peers and siblings. During later development periods, playing school was substituted by helping peers at school and then tutoring pupils and students. The respondents notice that they possess traits useful to teachers, like teaching, and at the same time achieve evident effects in this area. The beginning of shaping their own didactic competences is sought in childhood (e.g. I used to help, but I did not let others copy my work). People forming this type of story place didactic work above scientific work in the academic profession, in the field performed by them (e.g. Love teaching students. Research is a nice addition.).

The third type of narrative I practised competition tourism in a school, and later participated in conferences and Erasmus during studies is appropriate for those who give significant meaning to consecutive educational stages that create opportunities for comprehensive development and aspirations. Here, education is perceived as gaining new achievements, sometimes also as the need to face failures. Distinguishing from peers in terms of knowledge, skills and talents is a characteristic feature of people creating this type of narrative. Some of the stories revealed the difficulties the extremely talented students have to face. These were mainly problems in interpersonal relations with peers, lack of acceptance, the "nerd" label. The graduation exam passed with very good grades and starting studies in the dream specialisation was an important signal for some that outstanding academic performance is not an obstacle, but an advantage. At the same time, some narratives illustrated a thread of problems connected with the experience of the first educational failures (e.g. failure to get to the dream university, failing the exam at the university) despite previous successes and being one of the best students in the school/class. Academic profession is seen as a chance of lifelong learning and self-development in the course of life.

The following statement is characteristic for the fourth type of narrative: The professor offered me the $P h D$ studies. This narrative is appropriate both for people who had plans to undertake $\mathrm{PhD}$ studies and for those who did not even think about this. An invitation to cooperation at the university is perceived as ennoblement, distinction. Most often, this proposal was the result of previous good cooperation between the student and the research and didactic worker within the performed research projects, writing a dissertation, activities in a scientific club, etc. This type of narrative is almost absent in the educational biographies of $\mathrm{PhD}$ students in Ukraine.

The fifth type of narrative is appropriate for people who have already gained professional experience in the economy sector, and dissatisfaction with work in the profession was the basis for making a decision about $\mathrm{PhD}$ studies. This type of narrative is exemplified by the words: I have watched a monotonous life in a corporation and I understood that creative work takes place at universities and that fulfilled ambitions are more valued than the account balance. The respondents forming this type of narrative indicate numerous negative aspects of corporate work, among others, the lack/limited possibility of development, the performance of similar tasks, sense of anonymity, lack of autonomy. While they perceive the academic profession mainly as a challenge, they carry out stimulating tasks that contribute to the development of technology and civilisation, and the ability to fulfil their own ambitions. This type of narrative concerns only $\mathrm{PhD}$ students from Poland, it is absent in the biographies of $\mathrm{PhD}$ students in Ukraine.

Another type of narrative is very similar to the previous one and can be summarised by the statement: Such things can only be done by people with a PhD degree. It is common for people forming this kind of stories to undertake professional work (also in organisations outside the borders of their homeland) and tasks perceived as proper for people with a scientific degree within it. Therefore, a PhD degree is a pass to take part in innovative research projects aimed at developing new patents. Most PhD students in this group enter the so-called implementation doctorate and do not link their future with working at the university. Thus, a broader trend is evolving concerning the expansion of the scientific policy to the so-called corporate learning realised in parallel with academic education.

The next type of narrative concerns the instrumental role of being a $\mathrm{PhD}$ student. This type of narrative is exemplified by the words: Student status allows me to maintain certain privileges, so I want to be a student as long as it is possible. These privileges include, among others, social insurance, scholarship, discounts. Doctoral studies give a sense of safety in case of difficulties with finding a job or running own company. Postgraduate education is a kind of assurance, an activity guaranteeing some profits.

The last type of narrative results from the strong need to be a creator of changes in higher education, which arise on account of critical reflection on the current state of academic education. It is expressed in the statement: They teach many redundant things at the university. I want to change it, and in order to do this, I need a PhD degree! The respondents are convinced of the importance of education but understand it primarily as the appropriate training of graduates for the needs and requirements of the labour market. In their opinion, the higher education system should undergo an in-depth reform and offer curricula that are 
desirable by the students and their future employers. The academic profession is perceived as a mission academic teachers should adapt to the ongoing changes, social expectations and labour market requirements.

\section{Discussion}

The types of narratives presented here depict the significance of both the past and plans for the future in decision-making regarding undertaking $\mathrm{PhD}$ studies. As it has been hitherto specified, not all types of narratives were revealed both in the educational biographies of $\mathrm{PhD}$ students from Poland and from Ukraine. Among the most crucial similarities in the biographies of PhD students from both countries one can list: perceiving the appropriate social origin as biographical capital, the role of noteworthy people in shaping interests and aspirations (changes in the impact of individual people in this area in the course of growth, cf. Mazurek \& Vynoslavska, 2018), the relation of educational needs and the opportunities for their fulfilment with the external environment, the great importance of formal education (and above all academic education) for making a decision about doctoral studies, perceiving academic profession as a mission, opportunities for growth and creative work, development of passions and the use of one's own potential (i.e. research inquisitiveness, didactic competence). The following differences have also been observed in the educational biographies of young adepts of science: the relationship of global events with education and development are present only in narratives of doctoral students in Ukraine, greater saturation with events unrelated to formal education (including academic) in narratives and lifelines of $\mathrm{PhD}$ students in Poland, proposal to start a scientific career is much more frequent in the narratives of the Poles (the Ukrainians have rather perceived this as an independent decision, possibly inspired by family members), a higher degree of anxiety regarding their future and a floating (Bron, 2000) in the biographies of the Poles.

Undertaking $\mathrm{PhD}$ studies and completing them by defending a doctoral dissertation is the first milestone in the academic career in the European higher education systems. As it has been mentioned earlier, the situation of the academic staff and its prospects for the future are undergoing radical changes in Europe. Nonetheless, the conducted research confirms that the academic profession is attractive for young talented people even with the rising professional insecurity and strong competition. Although anxiety and a sense of uncertainty about the future are present in the analysed biographies. It is worth noting that the career of young scientists is strongly related to having support in the older generation of scientists, who on the one hand are intellectual leaders, and on the other - mentors introducing them into the world of science (see Kwiek \& Antonowicz, 2015; Kwiek, 2016, 2018). However, the older generation functioned in entirely different academic conditions from those the current doctoral students have to face. Therefore, they are not able to fully prepare them for the current academic reality. Overcoming milestones in the academic career will, therefore, be only the part of those who achieve better results in their research work and stand out in their field. This task is crucial because mobility between the higher education sector and the economic sector is often problematic (Kwiek, 2016).

The conducted research revealed the significance of constructing educational biography (from the perspective of an adult) of:

a) the environment of upbringing with the transferred heritage of social origin (including family traditions connected with the performance of the profession of a teacher or academic teacher),

b) the need of lifelong learning and development in the course of life,

c) formal education as a space that enables growth, transgression, experiencing successes, shaping and deepening interests, but at the same time creating certain restrictions or leading to the need of facing own weaknesses and educational failures (especially clear in the analysed biographies at the stage of academic education). The distancing to schools, universities and educational practices used by academic teachers visible in some biographies resulted in expressing the desire to change in this area through their own scientific and didactic activity. Obtaining the title of a doctor was perceived as a prerequisite to open the possibility of active participation in the change. In turn, this change was understood in two ways: 1) teaching students according to the requirements of the labour market and using own professional experience for this purpose, thus intensifying instrumental education, technological approach to own educational practices; 2) creating an opportunity for students to learn in the master-student relationship with special regard paid to the needs and predispositions of the students, the willingness to become a mentor for the students. In both cases, the motives for change were associated with the desire to create conditions for the students to grow that were not experienced or were experienced to a very little extent by doctoral students during their educational path,

d) social environment stimulating growth, showing opportunities and own predispositions, competences. Mostly representatives of the academic and corporate (the so-called implementation $\mathrm{PhD}$ programme) encourage undertaking $\mathrm{PhD}$ studies that open a gate to conducting scientific research. The clearly marked role of older scientists (most often professors promoting doctoral dissertations) in educational 
biographies of doctoral students from Poland confirms the correlation between the academic care and own scientific growth (including the decision to start such development). In turn, mainly peers and family members stimulate the undertaking of doctoral studies associated more with didactic and not scientific growth,

e) living environment which is a source of certain restrictions (e.g. lack of prospect to take up a job in the profession due to the lack of enterprises with an appropriate profile in the immediate surroundings) or prospects (e.g. universities that enable international cooperation and learning from experts in a given field),

f) dreams and aspirations of young adults and people from their immediate environment (especially family members) encouraging lifelong learning, systematic work and growth,

g) dilemmas related to making decisions about one's own future, which are particularly noticeable in young adults, as Arnett (2000) stressed in the emerging adulthood theory. The doctorate/academic profession is perceived in this context at least in two ways: as an alternative in the case of problems with finding a job in the economy sector (investing in oneself) and as an opportunity of postponing a decision about one's own future in time (working in the academia versus working in a corporation),

h) everyday life as a source of shaping the sense of responsibility and knowledge and competence necessary for coping in different situations.

\section{Conclusions}

In spite of the ongoing changes in the European higher education systems and the increasing expectations of scientific and didactic staff, with the simultaneous non-favourable changes in employment conditions at universities, working in academic institutions is still an attractive prospect for young talented people (see also Kwiek, 2016, 2018). It is sometimes perceived as the only profession creating opportunities for comprehensive development and autonomy. However, the lack of guarantee of employment at the university after defending a doctorate dissertation and lower remuneration in academic institutions compared to the economic sector make it difficult to plan one's own future, which consequently leads to a sense of being in limbo by many $\mathrm{PhD}$ students (in the presented studies, it mainly applies to Poland). The choice between an academic career and non-academic career is difficult.

On the basis of our own research, it can be determined that traditional motives of undertaking the academic profession - i.e. curiosity, professional status, and financial rewards - still play a big role. The first and the second seem to be the most crucial, while the material sphere moves to the background or entirely gives way to the first two motives. New motives are also appearing: investing in oneself and social mission. Investing in oneself results from the pragmatic approach to doctoral studies, i.e. it is connected to associating the academic degree with the possibility of undertaking more attractive and challenging work and optionally with the standing out from other university graduates (which is crucial in countries with high rates of education, such as Poland, Ukraine and others). In turn, the social mission has the emancipation potential and is connected with the need to initiate and implement significant changes both in the research and didactic sphere in higher education, as well as the need to do something valuable for people and the world.

There are a number of gaps in our knowledge around the significance of educational biographies of engineers in making decisions to start an academic career. An important result of the conducted project is a set of new questions that can be used as ideas for further research. The main aim of further research is to recognise how the cultural, social, economic and legal changes in the environment of the higher education institutions influence on PhD students' choice between an academic career and non-academic career. The next important objective of further research is to study how the educational biographies of engineers starting academic careers influence on forming their creative approach and responsible attitudes to concern the improvement of the university education quality, in particular in the context of wide implementation of new ICT (see also Vynoslavska, 2015; 2018).

\section{References:}

Adriansen, H.K. (2012). Timeline interviews: A tool for conducting life history research. Qualitative Studies, 3(1), $40-55$. https://doi.org/10.7146/qs.v3i1.6272

Alheit, P. (2009). Biographical learning - within the new lifelong learning discourse. In K. Illeris (Ed.), Contemporary Theories of Learning. Learning theorists... in their own words (pp.153-165). New York: Routledge. https://doi.org/10.4324/9781315147277

Arnett, J.J. (2000). Emerging Adulthood. A Theory of Development From the Late Teens Through the Twenties. American Psychologist, 55(5), 469-480. https://doi.org/10.1037//0003-066X.55.5.469

Arnault, D. S. \& Shimabukuro, S. (2011). The Clinical Ethnographic Interview: A user-friendly guide to the cultural formulation of distress and help seeking. Transcultural Psychiatry, 49(2), 302-322. https://doi.org/10.1177/1363461511425877

Baran, A. (ed.) (2007). Szkoly wyzsze i ich finanse w 2006 roku. Informacje i opracowania statystyczne [Higher Education Institutions and their Finances in 2006. Statistical Information and Elaborations]. Warsaw: Statistical Publishing Establishment.

Berends, L. (2011). Embracing the Visual: Using Timelines with In-depth Interviews on Substance Use and Treatment. The Qualitative Report, 16(1), 1-9. Retrieved December 19, 2018 from https://nsuworks.nova.edu/tqr/vol16/iss1/1 
Bron, A. (2000). Floating as an analytical category in the narratives of polish immigrants to Sweden. In E. Szwejkowska-Olsson, M. Bron, Jr. (Eds.), Allvarlig debatt och rolig lek, En festskrift tillägnad Andrzej Nils Uggla. Uppsala Universitet: Centrum för multietnisk forskning.

Derzhavna sluzhba statystyky Ukrayiny. Naukova ta innovatsiyna diyal'nist' Ukrayiny: statystychnyy zbirnyk [State Statistics Service of Ukraine. Scientific and innovative activity of Ukraine: statistical collection]. ( 2018). Retrieved December 19, 2018 from http: //www.ukrstat.gov.ua/druk/publicat/kat u/2018/zb/09/zb nauka 2017.pdf

Derzhavna sluzhba statystyky Ukrayiny. Naukova ta innovatsiyna diyal'nist' Ukrayiny: statystychnyy zbirnyk [State Statistics Service of Ukraine. Scientific and innovative activity of Ukraine: statistical collection]. (2008). Retrieved December 19, 2018 from http://www.ukrstat.gov.ua/druk/publicat/Arhiv u/16/Arch nay zb.htm

Dickinson, H. (1998). Perspectives on Learning Difficulties through Biographies. In M. Erben (Ed.), Biography and Education: A Reader. London: Falmer Press.

Dominice, P. (2000). Learning From Our Lives: Using Educational Biographies With Adults. San Francisco: Jossey Bass.

Fritz, E., \& van Zyl, G. (2015). Lifelines. A Visual Exploration of the Past in Order to Guide the Journey into the Future. In M. McMahon, M. Watson (Eds.), Career Assessment (pp.89-96). Qualitative Approaches. Sense Publishers. https://doi.org/10.1007/978-94-6300-034-5_10

Fumasoli, T., Goastellec, G., \& Kehm, B.M. (2015). Introduction. Understanding Change in the Academic Profession Through the Perceptions of Academics and Institutional Leadership. In T. Fumasoli, G. Goastellec, B. M. Kehm (Eds.), Academic Work and Careers in Europe: Trends, Challenges, Perspectives (pp.1-12). Dordrecht: Springer. https://doi.org/10.1007/978-3319-10720-2_1

Gramling, F. L., \& Carr, L. R. (2004). Lifelines: a life history methodology. Nursing Research, 53(3), 207-210. https://doi.org/10.1097/00006199-200405000-00008

Gromkowska-Melosik, A. (2015). Globalne rankingi uniwersytetow i akademicka gra o status [Global University Rankings and the Academic Status Game]. Studia Edukacyjne, 37, 7-21. https://doi.org/10.14746/se.2015.37.1

Jurgiel-Aleksander, A. (2015). Jaka edukacja i dlakogo? Biografie edukacyjne dorosrych i ich spoleczny wymiar [What kind of education and for whom? The educational biographies of adults and their social dimensions]. Rocznik Andragogiczny, 22, 79-100. http://dx.doi.org/10.12775/RA.2015.004

Kruchowska, E. (2010). Metoda wielostopniowa analizy interpretacji hermeneutycznej materiahi empirycznego [The multistage method for analysing the hermeneutic interpretation of an empirical material]. In M. Straś-Romanowska, B. Bartosz, M. Żurko (Eds.), Badania narracyjne w psychologii [Narrative research in psychology]. Warszawa: Wydawnictwo Psychologii i Kultury Eneteia.

Kwiek, M. (2018). Changing European Academics. A Comparative Study of Social Stratification, Work Patterns and Research Productivity. London and New York: Routledge. https://doi.org/10.4324/9781351182041

Kwiek, M. (2016). Kariera akademicka w Europie: niestabilność w warunkach systemowej konkurencji [An academic career in Europe: instability in the conditions of systemic competition]. Nauka $i$ Szkolnictwo Wyższe, 1(47), 203-245. https://doi.org/10.14746/nsw.2016.1.9

Kwiek, M, \& Antonowicz, D. (2015). The Changing Paths in Academic Careers in European Universities: Minor Steps and Major Milestones. In T. Fumasoli, G. Goastellec, B. M. Kehm (Eds.), Academic Careers in Europe - Trends, Challenges, Perspectives (pp.41-68). Dordrecht: Springer.

Mazurek, E. (2015). Lignes du developpement (educatif) dans les biographies - approche andragogique. In O.Czerniawska, A. Slowik (Eds.), Trajets de formation et approche biographique. Perspectives francaise et polonaise (pp.235-246). Paris: L'Harmattan.

Mazurek, E., \& Vynoslavska, O. (2018). Lifelines in studies on biographic determinants of decisions to take up PhD studies at a technical university. In Ł. Tomczyk, A. Ryk, J. Prokop (Eds.), Proceedings New trends and research challenges in pedagogy and andragogy NTRCPA18 (pp.151-160). Kraków: Uniwersytet Pedagogiczny w Krakowie. https://doi.org/10.24917/9788394156893.12

Postanova Kabinetu Ministriv Ukrayiny vid 23.03.2016 r. № 261 "Pro zatverdzhennya Poryadku pidhotovky zdobuvachiv vyshchoyi osvity stupenya doktora filosofiyi ta doktora nauk u vyshchykh navchal'nykh zakladakh (naukovykh ustanovakh)" [Resolution of the Cabinet of Ministers of Ukraine dated March 23, 2016 No. 261 "On Approval of the Procedure for Preparing Higher Educational Institutions for Ph.D. Degree and Doctor of Science in Higher Educational Institutions (Scientific Institutions)"]. (2016). Retrieved December 19, 2018 from https://www.kmu.gov.ua/ua/npas/248945529

Riessman, C. K. (2005). Narrative Analysis. In N. Kelly, Ch. Horrocks, K. Milnes, B. Roberts, D. Robinson (Eds.), Narrative, Memory \& Everyday Life (pp.1-7). Huddersfield: University of Huddersfield.

Stephan, P., \& Levin, S. (1992). Striking the Mother Lode in Science: The Importance of Age, Place, and Time. Oxford: Oxford University Press.

Vynoslavska, O. (2018). The Development of Creativity of the University Teacher in the Process of Pedagogical Activity. In International Multidisciplinary Conference "Science and Technology of the Present Time: Priority Development Directions of Ukraine and Poland", Vol.6 (pp. 11-14). Wolomin: Baltija Publishing.

Vynoslavska, O. (2015). Social Responsibility for ICT Implementation in the space of Higher Technical Education. In A. Kalus, E. Mazurek, J. Szymańska (Eds.), Architectura a Rozwój Człowieka: Ujęcie multidyscyplinarne. Wrocław: Politechnika Wrocławska.

Zyra, M. (ed.) (2017). Szkoly wyższe i ich finanse w 2016 roku. Informacje i opracowania statystyczne [Higher Education Institutions and their Finances in 2016. Statistical Information and Elaborations]. Warsaw: Statistical Publishing Establishment. 